\title{
Foot Hydrotherapy: Non-pharmacology Treatment for Reducing Anxiety in Third Trimester Pregnancy
}

\author{
Jumrah Sudirman ${ }^{1 *}$ (D), Nurjannah Bachri ${ }^{2}$ D, Muhammad Syafar ${ }^{3}$, Elizabet Catherine Jusuf ${ }^{4}$, Saidah Syamsuddin ${ }^{5}$, \\ Nasrudin Andi Mappaware ${ }^{6} \mathbb{D}$, Hasriani Saleng ${ }^{7}$ (i) \\ ${ }^{1}$ Doctoral Program, Medical Faculty, Hasanuddin University, Makassar, Indonesia; ${ }^{2}$ Pharmacy Study Program, Institute of \\ Health Science Tarumanegara, Tarumanegara, Indonesia; ${ }^{3}$ Department of Health Promotion, Public Health Faculty, Hasanuddin \\ University, Makassar, Indonesia; ${ }^{4}$ Department of Obstetrics and Gynecology, Medical Faculty, Hasanuddin University, Makassar, \\ Indonesia; ${ }^{5}$ Department of Psychiatry, Medical Faculty, Hasanuddin University, Makassar, Indonesia; ${ }^{6}$ Department of Obstetrics \\ and Gynecology, Medical Faculty, Muslim Indonesia University, Makassar, Indonesia; ${ }^{7}$ Department of Midwifery, Nursing and \\ Midwifery Faculty, Megarezky University, Makassar, Indonesia
}

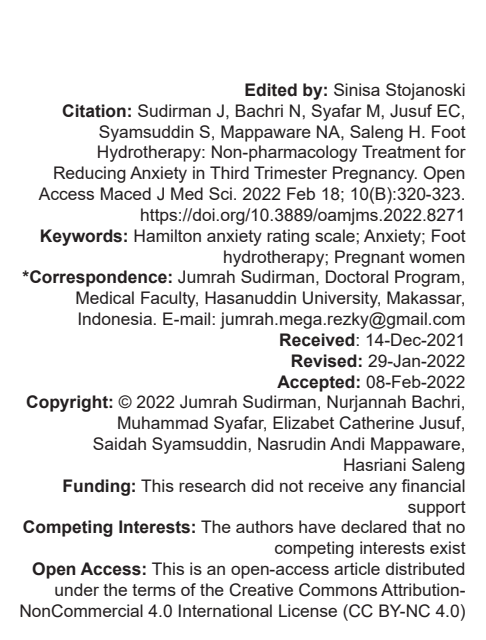

\section{Introduction}

Pregnancy is a natural process. Changes that occur in women during normal pregnancy are physiological rather than pathological. The changes can cause stress and anxiety or emotional maladaptation [1]. Excessive fear of pain, the birth process, and disabilities of the baby are part of the anxiety, especially in nullipara mothers [2], [3].

Anxiety during pregnancy can cause physical and psychological disorders, increasing the risk of morbidity in pregnant women and their fetuses [4]. The harmful effects of anxiety in pregnant women will stimulate an increase of stress hormones that can stimulate uterine contractions and increase blood pressure. It may trigger preeclampsia and increase the incidence of gestational diabetes [5], [6], [7]. Furthermore, the anxiety felt until delivery causes prolonged labor and often ends with cesarean section.
On the other hand, in terms of the psychoneurological aspect, maternal anxiety also influences the hypothalamus that affects hypophyses, stimulating the adrenal cortico tropic hormone. It impacts the adrenal glands and will produce cortisol in large quantities, which interferes with the neonatal [8], [9]. Moreover, the release of catecholamine causes placental dysfunction and obstacles to transport oxygen and various nutrient delivery to the fetus, leading to low birth weight, premature infants. In the long term, it is related to the child's behavioral disorder and emotion [10], [11], [12], [13], [14].

Various methods have been proven to have an impactonreducinganxiety, includingusingmurottaltherapy method, classical music, breathing relaxation method, meditation, and hydrotherapy [15], [16], [17], [18], [19]. Hydrotherapy is more efficient than other therapies since it is pretty economical and easier to do by pregnant women. Anxiety in pregnant women is a problem that may occur mainly in the third trimester of a pregnancy 
before giving birth. One of the methods used is water therapy, which refers to soaking the feet into warm water. This therapy has been proven to reduce pain and blood pressure in hypertension [20], [21].

Therefore, this research aims to examine the effect of foot hydrotherapy as non-pharmacological therapy for reducing pregnancy anxiety.

\section{Research Methods}

This study employed the Quasi-Experimental method with a comparative group. In this study, the population in this study were all pregnant women treated in Makassar primary health facilities from September 2019 to June 2020. The participants were 57 pregnant women in their third semester. It consisted of 30 mothers who got intervention and 27 mothers who were the control. In the control group, 3 respondents had resigned. Sample taking used consecutive sampling where all members of the population who meet the inclusion criteria are selected as research samples by using a large formula hypothesis sample test two independent groups. The gestational age criteria were between 28 and 38 weeks, primigravida, experienced anxiety, and ready to be respondents.

This hydrotherapy method was done by soaking the feet until the ankles in the warm water $\left(38-39^{\circ} \mathrm{C}\right)$ for approximately $15 \mathrm{~min}$. Treatment was given 3 times a day for 2 consecutive days.

The Hamilton Anxiety Rating Scale questionnaire was used to measure respondents' anxiety levels. The questionnaire consisted of 14 question items that had been tested. This measuring instrument had been tested for 25 people for a month. Using the Pearson Product Moment test, the test results with the calculated $r$-value (0.39-0.79), $\alpha=0.05$. While the reliability test results obtained alpha Cronbrach's $r$ count was $0.948>r$ table $(0.6)$, it meant reliable. Data analysis was carried out by univariate and bivariate. Bivariate analysis was conducted using paired samples t-test to assess changes before and after treatment and Independent t-test to compare the intervention and control groups.

\section{Results}

Table 1 shows the most respondents in the age of 20-29 years old (23 respondents $(76.7 \%$ ) in the intervention group and 18 respondents $(66.7 \%)$ in the control group). They mainly were graduated from senior high school (18 respondents $(60 \%)$ in the
Table 1: Characteristics of respondents based on age, education, and family income

\begin{tabular}{|c|c|c|c|c|}
\hline \multirow[t]{2}{*}{$\begin{array}{l}\text { Variable } \\
\text { nat }\end{array}$} & \multicolumn{2}{|c|}{ Intervention } & \multicolumn{2}{|c|}{ Control } \\
\hline & $\mathrm{n}$ & $\%$ & $\mathrm{n}$ & $\%$ \\
\hline \multicolumn{5}{|l|}{ Group of age } \\
\hline $16-19($ y.o) & 7 & 23.3 & 9 & 33.3 \\
\hline $20-29$ (у.о) & 23 & 76.7 & 18 & 66.7 \\
\hline \multicolumn{5}{|l|}{ Mother's education } \\
\hline Junior high school & 7 & 23.3 & 8 & 29.6 \\
\hline Senior high school & 18 & 60.0 & 16 & 59.3 \\
\hline University & 5 & 16.7 & 3 & 11.1 \\
\hline \multicolumn{5}{|l|}{ Family income } \\
\hline Low & 25 & 83.3 & 17 & 63 \\
\hline Middle & 5 & 16.7 & 10 & 37 \\
\hline Total & 30 & 100 & 27 & 100 \\
\hline
\end{tabular}

intervention group and 16 respondents (59.3\%) in the control group). Meanwhile, low income was dominated the family income (25 respondents $(83.3 \%)$ in the intervention group and 17 respondents (63\%) in the control group).

Table 2 shows that the anxiety values in the two groups were almost the same $(21 \pm 2.3$ dan $22.07 \pm 1.99$ ) before treatment. However, the anxiety level went down after treatment in the intervention group; in the control group, the anxiety score increased on the $3^{\text {rd }}$ day after the pretest. Bivariate analysis using an Independent t-test obtained a significant value that showed the effect of hydrotherapy on the anxiety level of pregnant women $(p=0.000)$.

Table 2: The effect of foot hydrotherapy on the anxiety level among women in third-trimester of pregnancies

\begin{tabular}{lllll}
\hline Variable & Total $(\mathrm{n})$ & $\begin{array}{l}\text { Before treatment } \\
\text { Mean } \pm \mathrm{SD}\end{array}$ & $\begin{array}{l}\text { After treatment } \\
\text { Mean } \pm \text { SD }\end{array}$ & p-value \\
\hline Anxiety & & & & \\
$\quad$ Intervention Group & 30 & $21 \pm 2.3$ & $16.6 \pm 2.84$ & 0.000 \\
$\quad$ Control Group & 27 & $22.07 \pm 1.99$ & $23.37 \pm 1.49$ & \\
\hline
\end{tabular}

\section{Discussion}

This research demonstrates that hydrotherapy decreases anxiety in pregnant women in this research. As indicated in Table 1, most respondents aged 20-29 years old, graduated from senior high school, with low income. This finding shows the significant effectiveness of foot hydrotherapy with warm water in reducing anxiety in pregnant women in the third trimester $(p=0.000)$.

Foot Hydrotherapy with warm water is based on the principle of heat transfer through conduction, which is the transfer of heat from warm water to the body, causing blood vessels to become wider and muscle tension to decrease; blood circulation is smooth, reducing the level of anxiety in pregnant women [20], [22], [23]. Implementation of foot hydrotherapy with warm water could reduce mild and moderate anxiety levels experienced by pregnant women in the third trimester, indicated by the decrease or the body's response to anxiety. Soaking feet into warm water should be done repeatedly and 
regularly, 3 times within 2 days at a temperature of $38-40^{\circ} \mathrm{C}$, so the benefits of Foot Hydrotherapy could be immediately felt by respondents [19], [21].

Foot hydrotherapy gives a feeling of warmth, which will directly touch the skin of the foot where there are many blood vessels and nerves, such as the flexus venous. The stimulation is transmitted to the posterior horn and the spinal cord. From here, it is forwarded to lamina I, II, III dorsalis radix, then to the ventral basal thalamus, and into the brain stem. Here, there is a soporific effect (sleepiness). Therefore, foot hydrotherapy, soaking feet into warm water, will make pregnant mothers more relaxed [20], [24], [25].

Foot soaks can reduce anxiety symptoms, such as cardiovascular, respiratory, and gastrointestinal symptoms. Foot hydrotherapy as a non-pharmacological treatment will affect arterial pressure by baroreceptors in the cortical sinus and aortic arch, which will convey impulses carried by nerve fibers carrying cues from all parts of the body to inform the brain about blood pressure, blood volume, and all special needs of all organs to the sympathetic nerve center and medulla [24], [26]. There is a dilation of blood vessels. Blood flow will be smooth. So, it is easy to push blood into the heart and reduce systolic pressure. The state of isovolumic ventricular relaxation causes the pressure in the ventricles to drop dramatically, causing a smoother blood flow. This will decrease diastolic pressure and reduce anxiety symptoms in pregnant women [23], [27].

However, one respondent experienced persistent anxiety before and after treatment with several symptoms, including losing interest in hobbies, feeling tense, insomnia, lack of sleep, hard to breath, fast heart rate, urination, and others. These symptoms persisted after the Foot Hydrotherapy using warm water due to the particular respondent's characteristics and psychosis, such as young age, low level of education, and low-family income [28], [29].

\section{Conclusion}

Foot hydrotherapy using warm water is a nonpharmacological therapy given to pregnant women to reduce anxiety, especially before giving birth (prenatal). It is an easy and efficient technique.

\section{Acknowledgments}

The researchers would like to thank Rizka Apriani of Megarezky University, who supported this research.

\section{References}

1. Veringa IK, de Bruin EI, Bardacke N, Duncan LG, van Steensel FJ Dirksen CD, et al. "I've changed my mind", mindfulness-based childbirth and parenting (MBCP) for pregnant women with a high level of fear of childbirth and their partners: Study protoco of the quasi-experimental controlled trial. BMC Psychiatry. 2016;16(1):1-14. https://doi.org/10.1186/s12888-016-1070-8

PMid:27821151

2. Offerhaus PM, Hukkelhoven $\mathrm{CW}$, de Jonge $\mathrm{A}$, van der Pal-de Bruin KM, Scheepers PL, Lagro-Janssen AL. Persisting rise in referrals during labor in primary midwife-led care in The Netherlands. Birth. 2013;40(3):192-201. https://doi.org/10.1111/birt.12055 PMid:24635504

3. Gökçe İsbir G, İnci F, Önal H, Yıldız PD. The effects of antenatal education on fear of childbirth, maternal self-efficacy and posttraumatic stress disorder (PTSD) symptoms following childbirth: An experimental study. Appl Nurs Res. 2016;32:227-32. https:// doi.org/10.1016/j.apnr.2016.07.013

PMid:27969033

4. Kannenberg K, Weichert J, Rody A, Banz-Jansen C. Treatmentassociated anxiety among pregnant women and their partners What is the influence of sex, parity, age and education? Geburtshilfe Frauenheilkd. 2016;76(7):809-13. https://doi. org/10.1055/s-0042-101546

PMid:27582579

5. Ross GP, Falhammar H, Chen R, Barraclough H, Kleivenes O, Gallen I. Relationship between depression and diabetes in pregnancy: A systematic review. World J Diabetes. 2016;7(19):554-71. https://doi.org/10.4239/wjd.v7.i19.554 PMid:27895824

6. Uvnäs-Moberg K, Ekström-Bergström A, Berg M, Buckley $S$, Pajalic Z, Hadjigeorgiou $\mathrm{E}$, et al. Maternal plasma levels of oxytocin during physiological childbirth-a systematic review with implications for uterine contractions and central actions of oxytocin. BMC Pregnancy Childbirth. 2019;19(1):1-17. https:// doi.org/10.1186/s12884-019-2365-9

PMid:31399062

7. Sudirman J, Sampara N, Mawang S, Passe R, Aswan R, Ahmad M. The analysis of reducing blood glucose levels of diabetics with diabetes mellitus by giving a secang wood stew (Caesalpinia sappan L.) to menopausal women in Makassar City. Enferm Clín. 2020;30:506-9.

8. Su Q, Zhang H, Zhang Y, Zhang H, Ding D, Zeng J, et al. Maternal stress in gestation: Birth outcomes and stress-related hormone response of the neonates. Pediatr Neonatol. 2015;56(6):376-81. https://doi.org/10.1016/j.pedneo.2015.02.002

PMid:26363772

9. O'Donnell K, O'Connor TG, Glover V. Prenatal stress and neurodevelopment of the child: Focus on the HPA axis and role of the placenta. Dev Neurosci. 2009;31(4):285-92. https://doi. org/10.1159/000216539

PMid:19546565

10. Davis EP, Glynn LM, Schetter CD, Hobel C, Chicz-Demet A, Sandman CA. Prenatal exposure to maternal depression and cortisol influences infant temperament. J Am Acad Child Adolesc Psychiatry. 2007;46(6):737-46. https://doi.org/10.1097/ chi.0b013e318047b775 PMid: 17513986

11. Talge NM, Neal C, Glover V. Antenatal maternal stress and long-term effects on child neurodevelopment: How and why? J Child Psychol Psychiatry. 2007;48(3-4):245-61. https://doi. org/10.1111/j.1469-7610.2006.01714.x

PMid: 17355398 
12. Fan F, Zou Y, Zhang Y, MaX, Zhang J, Liu C, et al. The relationship between maternal anxiety and cortisol during pregnancy and birth weight of chinese neonates. BMC Pregnancy Childbirth. 2018;18(1):265. https://doi.org/10.1186/s12884-018-1798-x PMid:29945557

13. Diego MA, Jones NA, Field T, Hernandez-Reif M, Schanberg S, Kuhn C, et al. Maternal psychological distress, prenatal cortisol, and fetal weight. Psychosom Med. 2006;68(5):747-53. https:// doi.org/10.1097/01.psy.0000238212.21598.7b

PMid:17012528

14. Ding XX, Wu Y Le, Xu SJ, Zhu RP, Jia XM, Zhang SF, et al. Maternal anxiety during pregnancy and adverse birth outcomes: A systematic review and meta-analysis of prospective cohort studies. J Affect Disord. 2014;159(81):103-10. https://doi. org/10.1016/j.jad.2014.02.027

PMid:24679397

15. Mamlukah M, Hadisaputro S, Soejoenoes A, Shaluhiyah Z, Syukur MA. Therapeutic effect of al-quran murattal on anxiety, sFlt-1, PIGF and sFlt-1/PIGF ratio in pregnant women with risk of preeclampsia. Int J Res Med Sci. 2019;7(5):1425.

16. Salafas $E$, Lestari $P$, Listiyaningsih $M$. The effectiveness of music therapy in reducing anxiety in third trimester of pregnancy. Siklus J Res Midwifery Politeknik Tegal. 2020;9(1):39-44.

17. Bastani F, Hidarnia A, Montgomery KS, Aguilar-Vafaei ME, Kazemnejad A. Does relaxation education in anxious primigravid Iranianwomeninfluenceadversepregnancyoutcomes?Arandomized controlled trial. J Perinat Neonatal Nurs. 2006;20(2):138-46. https:// doi.org/10.1097/00005237-200604000-00007

PMid: 16714913

18. van den Heuvel MI, Donkers FC, Winkler I, Otte RA, Van den Bergh BR. Maternal mindfulness and anxiety during pregnancy affect infants neural responses to sounds. Soc Cogn Affect Neurosci. 2013;10(3):453-60. https://doi.org/10.1093/scan/ nsu075

PMid:24925904

19. Benfield RD, Hortobágyi T, Tanner CJ, Swanson M, Heitkemper MM, Newton ER. The effects of hydrotherapy on anxiety, pain, neuroendocrine responses, and contraction dynamics during labor. Biol Res Nurs. 2010;12(1):28-36. https:// doi.org/10.1177/1099800410361535

PMid:20453024
20. Ummiyati M, Asrofin B. Efektifitas Terapi Air Hangat Terhadap Penurunan; 2019. p. 163-70.

21. Schitter AM, Nedeljkovic M, Baur H, Fleckenstein J, Raio L. Effects of passive hydrotherapy WATSU (WaterShiatsu) in the third trimester of pregnancy: Results of a controlled pilot study. Evid Based Complement Alternat Med. 2015;2015:437650. https://doi.org/10.1155/2015/437650 PMid:25815033

22. Hardianti I, Nisa K, Wahyudo R, Kedokteran F, Lampung U, Fisiologi $\mathrm{B}$, et al. Manfaat metode perendaman dengan air hangat dalam menurunkan tekanan darah pada penderita hipertensi benefits of immersion method with warm water in lowering blood pressure on hypertension patients. Medula. 2018;8:61-4.

23. Henrique AJ, Gabrielloni MC, Rodney P, Barbieri M. Nonpharmacological interventions during childbirth for pain relief, anxiety, and neuroendocrine stress parameters: A randomized controlled trial. Int J Nurs Pract. 2018;24(3):e12642. https://doi. org/10.1111/ijn. 12642

24. Masriadi, Eha S. Effectiveness of foot soak therapy with warm water on decreasing blood pressure in patients with stage one hypertension, Indonesia. Indian J Forensic Med Toxicol. 2019;13(3):386-91.

25. Mooventhan A, Nivethitha L. Scientific evidence-based effects of hydrotherapy on various systems of the body. North Am J Med Sci. 2014;6(5):199-209.

26. Koesnadi RS. Effect of warm water foot soak on sleep fulfillment in patients. J Kesehatan. 2017;5(2):82-7.

27. Ulya FH. The effect of feet soaking with warm water on the level of anxiety in pregnant women. EMBRIO. 2019;11:2. https://doi. org/10.36456/embrio.vol11.no2.a2044.

28. Soto-Balbuena C, Rodríguez MF, Gomis Al, Barriendos FJ, Le HN, Blanco CF, et al. Incidence, prevalence and risk factors related to anxiety symptoms during pregnancy. Psicothema. 2018;30(3):257-63. https://doi.org/10.7334/ psicothema2017.379

PMid:30009746

29. Omidvar S, Faramarzi M, Hajian-Tilak K, Amiri FN. Associations of psychosocial factors with pregnancy healthy life styles. PLoS One. 2018;13(1):e0191723. https://doi.org/10.1371/journal. pone. 0191723

PMid:29370250 